Article

\title{
Apoptosis Activation in Human Lung Cancer Cell Lines by a Novel Synthetic Peptide Derived from Conus californicus Venom
}

\author{
Irasema Oroz-Parra ${ }^{1}$, Mario Navarro ${ }^{2}$, Karla E. Cervantes-Luevano ${ }^{1,3}$, \\ Carolina Álvarez-Delgado ${ }^{1}$, Guy Salvesen ${ }^{2}$, Liliana N. Sanchez-Campos ${ }^{1}$ and \\ Alexei F. Licea-Navarro ${ }^{1, *}$ \\ 1 Biomedical Innovation Department, Scientific Research and High Education Center of Ensenada (CICESE), \\ Carretera Ensenada-Tijuana No 3918 Fracc, Zona Playitas Ensenada C.P. 22860, Baja California, Mexico; \\ oroz@cicese.edu.mx (I.O.-P.); karla.cervantes@icgeb.org (K.E.C.-L.); alvarezc@cicese.mx (C.A.-D.); \\ lsanchez@cicese.edu.mx (L.N.S.-C.) \\ 2 Cancer Center, Stanford Burnham Prebys Medical Discovery Institute, 10901 North Torrey Pines Road, \\ La Jolla, CA 92037, USA; mnavarro@sbpdiscovery.org (M.N.); gsalvesen@sbpdiscovery.org (G.S.) \\ 3 International Centre for Genetic Engineering and Biotechnology, Padriciano 99, 34149 Trieste, Italy \\ * Correspondence: alicea@cicese.mx; Tel.: +52-646-1750-500 (ext. 27200)
}

Academic Editor: Macdonald Christie

Received: 28 November 2015; Accepted: 28 January 2016; Published: 5 February 2016

\begin{abstract}
Lung cancer is one of the most common types of cancer in men and women and a leading cause of death worldwide resulting in more than one million deaths per year. The venom of marine snails Conus contains up to 200 pharmacologically active compounds that target several receptors in the cell membrane. Due to their diversity and specific binding properties, Conus toxins hold great potential as source of new drugs against cancer. We analyzed the cytotoxic effect of a 17-amino acid synthetic peptide (s-cal14.1a) that is based on a native toxin (cal14.1a) isolated from the sea snail Conus californicus. Cytotoxicity studies in four lung cancer cell lines were complemented with measurement of gene expression of apoptosis-related proteins Bcl-2, BAX and the pro-survival proteins NFKB-1 and COX-2, as well as quantification of caspase activity. Our results showed that H1299 and H1437 cell lines treated with s-call4.1a had decreased cell viability, activated caspases, and reduced expression of the pro-survival protein NFkB-1. To our knowledge, this is the first report describing activation of apoptosis in human lung cancer cell lines by s-cal14.1a and we offer insight into the possible mechanism of action.
\end{abstract}

Keywords: lung cancer; synthetic peptide; apoptotic-related genes; caspase-3 and -7; apoptosis; pathway

\section{Introduction}

Lung cancer is one of the most common types of oncological malignancies and remains the leading cause of cancer-related deaths, representing approximately $15 \%$ of all cases worldwide $[1,2]$. Despite all efforts to advance surgical procedures, radiotherapy and chemotherapy, the five-year survival rate for lung cancer patients has remained almost constant over the past three decades and persists at a dismal 15\% [3,4]. Thus, there is an increasing emphasis on strategies to maximize tumor control, prolong survival, minimize chemotherapy side effects and improve quality of life for patients [5].

Venoms are an extraordinary source of novel peptides, some of these have found applications to treat several pathologies in humans [6]. The large biodiversity offered by venom peptides, especially conotoxins isolated from the venom of predatory marine snails Conus, hold great promise for the development of peptide-based drugs [7]. The genus Conus consists of 500-700 species [8-10] and the venom of each species contains up to 200 pharmacologically active components that specifically target membrane receptors, ion channels and transporters in the nervous system [11-14]. 
Apoptosis, a vital biological process of multicellular organisms is mediated by the activation of proteases named caspases [15-17]. Apoptosis and caspase activation may take place via two major signaling systems: (1) the extrinsic or death receptor pathway, which is triggered via specific cell membrane receptors; and (2) the intrinsic or mitochondrial pathway triggered upon disruption of mitochondria and release of cytochrome c [18-22]. A third signaling system has been reported: the granzyme B pathway, where the cytotoxic cell protease granzyme B is delivered to sensitive target cells [23]. Deregulation of apoptosis either by loss of pro-apoptotic signals or by gain of anti-apoptotic signals can lead to initiation, promotion and progression of cancer, and it may also result in therapy failure [24]. Successful elimination of cancer cells from the body depends on activation of cell death by apoptosis, thus developing peptides to stimulate caspase activation and apoptosis execution represent a promising strategy to develop cancer chemotherapeutics [5].

In the present study, we analyze the cytotoxic properties of a synthetic peptide derived from the toxin cal14.1a isolated from Conus californicus. s-cal14.1a is part of a new superfamily named $\mathrm{J}_{2}$ [25] and conserve a cysteine pattern with other Conus toxins that are active against acetylcholine nicotinic receptors (nAChRs). The amino acid residues in the sequence of s-cal14.1a and the cysteine pattern are fundamental for the activity and affinity of $\alpha$-conotoxins [26-28]. nAChRs expression was thought to be restricted to neuronal and muscle cells, but emerging research shows that nAChRs are widely expressed in mammalian cells, including caner cells [29]. nAChRs may play key roles in pathogenesis as these interact with its agonists leading to activation of multiple signaling pathways that regulate progression, growth and metastasis of tumors [2,30,31]. Here we studied the cytotoxic properties of s-cal14.1a in four lung cancer cell lines, we quantified the expression of genes involved in execution and regulation of apoptosis namely Bcl-2, BAX and the pro-survival proteins NFKB-1 and COX-2, we also analyzed caspase activity. Our results indicate that s-cal14.1a induces down regulation of anti-apoptosis genes at the same time that leads to activation of DEVD-ase activity that is diagnostic for activity of caspase- 3 and -7 , two key caspases in the execution of the apoptotic pathway.

\section{Results}

\subsection{Effect of s-cal14.1a on Lung Cancer Cells Viability}

Activity of s-cal14.1a against lung cancer cell lines H1299, H1437, H1975 and H661 was evaluated using the MTS assay [32]; in all cell lines we observed decreased cell viability after $24 \mathrm{~h}$, up to $30 \%$, with respect to untreated cells (Figure 1). In all experiments, staurosporine was used as a positive control (C+). Staurosporine is an alkaloid isolated from Streptomyces staurosporeus known to activate apoptosis in several cancer cells [33]. Complete medium was added as negative control (C-).

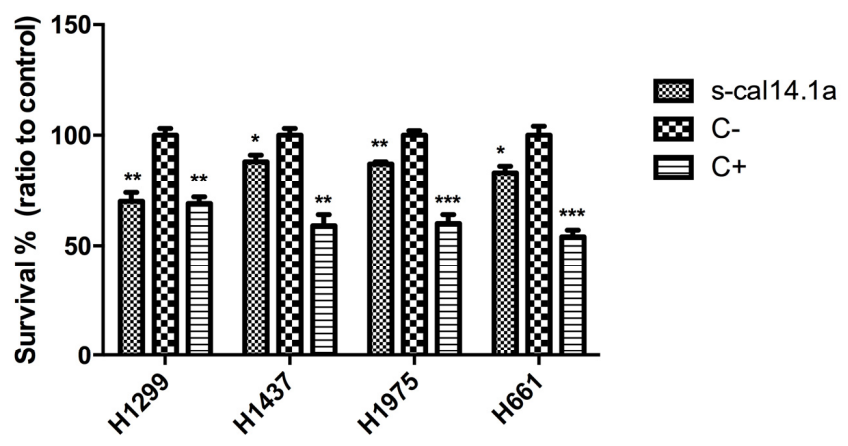

Figure 1. Effect of s-cal14.1a on cell viability. Lung cancer cells H1299, H1437, H1975 and H661 were seeded on 96-well plates and treated with $27 \mu \mathrm{M}$ of s-cal14.1a for $24 \mathrm{~h}$. Cell viability was determined by measuring absorbance in wells at $490 \mathrm{~nm}$ with MTS assay. Results were normalized to untreated cells $(\mathrm{C}-$ ) to obtain the percentage of cell viability and are expressed as the mean $\pm \mathrm{SEM}$. Positive control $(\mathrm{C}+) 5 \mu \mathrm{M}$ of staurosporine. Experiments were done in triplicates. ${ }^{*} p<0.05,{ }^{* *} p<0.01$ and *** $p<0.001$ vs. C - (unpaired $t$ Student's test). 


\subsection{Expression Analysis of Apoptotic-Related Genes}

The effect of s-cal14.1a on mRNA expression of selected genes was analyzed by RT-qPCR. The threshold cycles (CT) of the reference gene ( $\beta$-actin) and the target genes $(\mathrm{Bcl}-2, \mathrm{BAX}, \mathrm{NF} \kappa \mathrm{B}-1$ and COX-2) were determined in each sample. The relative mRNA expression of each gene analyzed was normalized against $\beta$-actin gene and then against the $C$ - of each treatment as calculated by the relative standard curve method [34].

Cells were incubated with $54 \mu \mathrm{M}$ s-cal14.1a for $24 \mathrm{~h}$, after this period gene expression was measured. s-cal14.1a increased levels of BAX mRNA in H1299 cells, but C+ decrease its expression (Figure 2A). It is known that BAX codes for a pro-apoptotic protein [35], therefore, we expected similar expression of BAX levels between cells treated with s-cal14.1a and staurosporine. Bcl-2 transcript levels appeared to be vastly increased with s-cal14.1a and the $\mathrm{C}+$, this is contradictory to our expectations because Bcl-2 is an anti-apoptotic protein [36]. Regarding the expression of NFKB-1 and COX-2 in H1299 cell line, cal14.1a induced a level of expression as that observed in the control (Figure 2A).

s-cal14.1a and C+ increased expression of Bcl-2 in H1437 cell line (Figure 2B). NFkB-1 mRNA levels showed a minor decline compared to $\mathrm{C}+$ which had a considerable decrease after $24 \mathrm{~h}$ of treatment. BAX and COX-2 genes showed no significant difference compared to $\mathrm{C}-$, but $\mathrm{C}+$ reduced the expression of both genes. Additionally BAX protein levels were analyzed by Western blot. The results obtained (Figure S1A,B) are in agreement with the mRNA expression profile for BAX in H1437 cell line, i.e., treatment with staurosporine decreased the relative protein expression of BAX, while treatment with s-cal14.1a had no effect in protein expression when compared to $\mathrm{C}-$. These findings suggest that treatment with s-cal14.1a induces similar results at the protein and mRNA levels. Taking this into account, we assume that the effect of s-cal14.1a on mRNA expression profile would be similar at the protein level. In H1975 cells treated with s-cal14.1a Bcl-2, mRNA levels were slightly up-regulated (Figure 2C), but the $\mathrm{C}+$ showed no difference compared to $\mathrm{C}-$. BAX expression did not show significant differences in neither s-cal14.1a nor C+ treatments. In H1975 cells, expression levels of NFkB-1 were equivalent in treatment with s-cal14.1a and staurosporine. COX-2 levels showed no difference between non-treated cells and those treated with s-cal14.1a. However, treatment with staurosporine induced considerable increase of COX-2 after $24 \mathrm{~h}$.

Treatment of H661 cells with s-cal14.1a showed a 2-fold increase Bcl-2 levels, while cells treated with staurosporine Bcl-2 expression was increased 8-fold (Figure 2D), as previously shown in the other three cell lines analyzed. Levels of NFKB-1 and COX-2 did not showed significant difference with s-cal14.1a treatment compared to the non-treated control.

Expression of apoptotic-related genes in four cancer cell lines had an interesting outcome. In the case of Bcl-2, its mRNA levels were increased in all the cell lines tested after $24 \mathrm{~h}$ of treatment with s-cal14.1a and C+, since Bcl-2 is an anti-apoptotic protein we expected to find decreased levels of this gene. Moreover, expression of the pro-apoptotic gene BAX was increased in H1299 cell (Figure 2A) after the treatment with s-cal14.1a, but in H1437, H1975 and H661 (Figure 2B,C) had no significant difference, both BAX and Bcl-2 genes behaved contrary to expectations. Expression levels of NFkB-1 and COX-2 were different in all cell lines tested, NFkB-1 was increased with s-cal14.1a in H1299 cells, whereas, in H1437 and H1975 were decreased. The NFkB signaling pathway plays an important function in promoting survival and growth of tumor cells [37]. COX-2 was slightly increased with s-cal14.1a and C+ in H1299; in the others cell lines, no significant difference was observed. Although these results are somewhat contradictory to our expectations Bcl-2, BAX, NFkB-1 and COX-2 are only four of the different genes involved in regulation of apoptosis. A more global analysis could reveal changes in gene expression that were not reflected in the genes analyzed. 

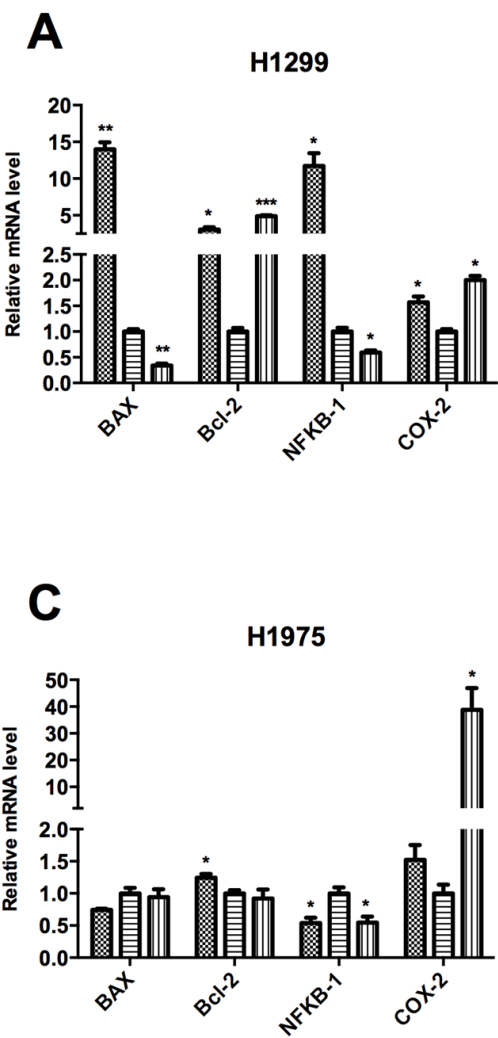

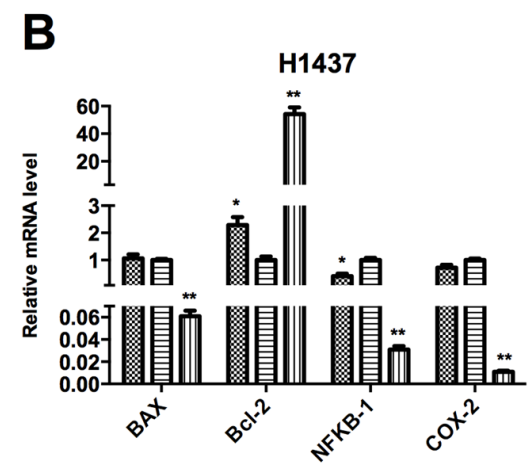

s-cal14.1a

E C-

D

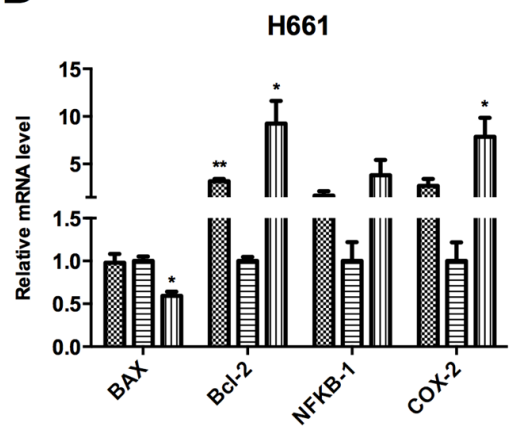

Figure 2. mRNA expression profile of BAX, Bcl-2, NFkB-1 and COX-2 in H1299 (A); H1437 (B); H1975 (C); and H661 (D) cell lines. A total of $1 \times 10^{6}$ cells were treated with $54 \mu \mathrm{M}$ of s-cal14.1a for $24 \mathrm{~h}$. Total RNA was isolated and treated with DNase, $2 \mu \mathrm{g}$ were reverse-transcribed with SuperScript III Kit, using $\operatorname{oligodT}_{20}$ and a random hexamer. mRNA levels were compared by RT-qPCR. Results were normalized to the $\beta$-actin gene and expressed as the mean \pm SD relative to the negative control $(C-$, untreated cells). As positive control $(\mathrm{C}+)$ cells were treated with $7 \mu \mathrm{M}$ of staurosporine. Experiments were done in triplicate. ${ }^{*} p<0.05,{ }^{* *} p<0.01$ and ${ }^{* * *} p<0.001$ vs. C- (unpaired Student's t-test).

\subsection{Activation of Caspase-3 and -7 in Lung Cancer Cell Lines}

To determine if s-cal14.1a promotes cell death in lung cancer cell lines we analyzed apoptosis activation. Apoptosis execution depends on the proteolytic activity of caspase- 3 and -7 which in turn cleave proteins substrates that bring cells to metabolic dismay [38]. After incubation of cell lines with s-cal14.1a we assessed caspase- 3 and -7 activity by fluorescence microscopy using the commercial kit CellEvent ${ }^{\mathrm{TM}}$ Caspase-3/7 that is based on the emission of fluorescence upon cleavage of the fluorescently labeled DEVD peptide. In addition, cells were stained with nuclear dyes Hoechst 33342 and propidium iodide (PI), that is also used to identify necrotic or apoptotic cells. After taking images at different time points we calculated the percent of positive cells to caspase- 3 and -7 activation and labeled with PI. It is noteworthy that the images do not always match the cell counts in the graphs, this is because the image covers a limited area for all pictures taken and the counting is for all the cells in the field of analysis.

After incubation with s-cal14.1a H1299 cells showed major activation of caspase-3 and -7 at $12 \mathrm{~h}$ ( $41 \%$ of positive cells Figure 3B) while at $6 \mathrm{~h}$ and $24 \mathrm{~h}$ the number of positive cells were $22 \%$ and $21 \%$, respectively. Cells treated with staurosporine displayed $36 \%$ of positive cells throughout the time of the experiment. These results indicate that $\mathrm{H} 1299$ cells are more sensitive to s-cal14.1a than to staurosporine. 


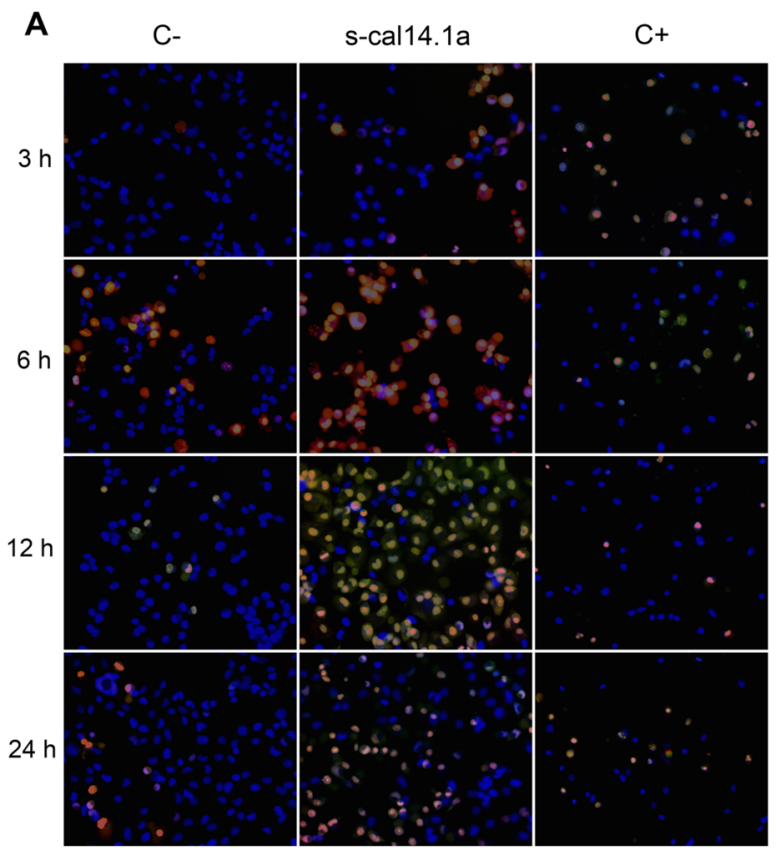

B

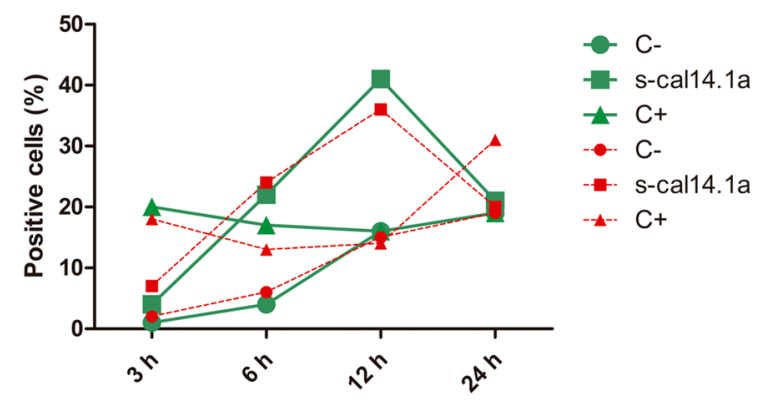

Figure 3. Time course of caspase- 3 and -7 activation in cell line H1299. Cells were treated with $27 \mu \mathrm{M}$ of s-cal14.1a for 3, 6, 12 and $24 \mathrm{~h}$ the incubated with CellEvent ${ }^{\mathrm{TM}}$ Caspase-3/7 (green), Hoechst 33342 (blue) and PI (red) for $30 \mathrm{~min}$ at $37^{\circ} \mathrm{C}$ and $5 \% \mathrm{CO}_{2}$. (A) Representative images showing untreated cells $(\mathrm{C}-)$, cells treated with s-cal14.1a and C+ $(1 \mu \mathrm{M}$ staurosporine $)$ at $460 \times$ overall magnification; (B) Count of positive cells to the different dyes. Cells stained blue were considered as $100 \%$. Results are expressed as the percentage of cells that are positive to caspase- 3 and -7 (green) and PI (red).

Activation of caspase- 3 and -7 in the $\mathrm{H} 1437$ cell line shows $22 \%$ of positive cells after $3 \mathrm{~h}$ of treatment with s-cal14.1a (Figure 4B), followed by a considerable decrease at $6 \mathrm{~h}$ and $12 \mathrm{~h}(5 \%)$ and a final increase at $24 \mathrm{~h}(14 \%)$. Treatment with staurosporine induced (64\%) caspases activation after $24 \mathrm{~h}$ of incubation. This result differs from H1299 cells that activate a major percentage of caspases at $6 \mathrm{~h}$ and $12 \mathrm{~h}$, which may indicate that activation of caspase- 3 and -7 depends on the type of cell and on the stimulus used to induce apoptosis [39].

Regarding H1975 and H661, neither of the two cell lines showed more than $7 \%$ of positive cells to caspase-3 and -7 with s-cal14.1a treatment at any time (Figures 5A and 6A). H1975 and H661 cells treated with staurosporine showed $27 \%$ and $34 \%$ of positive cells, respectively (Figures 5B and 6B). These types of cells appear to be more resistant to apoptosis activation and may need longer incubation with the toxin or a higher concentration.

All cell lines showed a similar percentage of positive cells to PI and caspase-3 and -7. After s-cal14.1a treatment, H1299 and H1437 cells showed a large percent of positive cells to PI. This confirms the results obtained with caspase- 3 and -7 and demonstrates that s-cal14.1a induces apoptosis. 

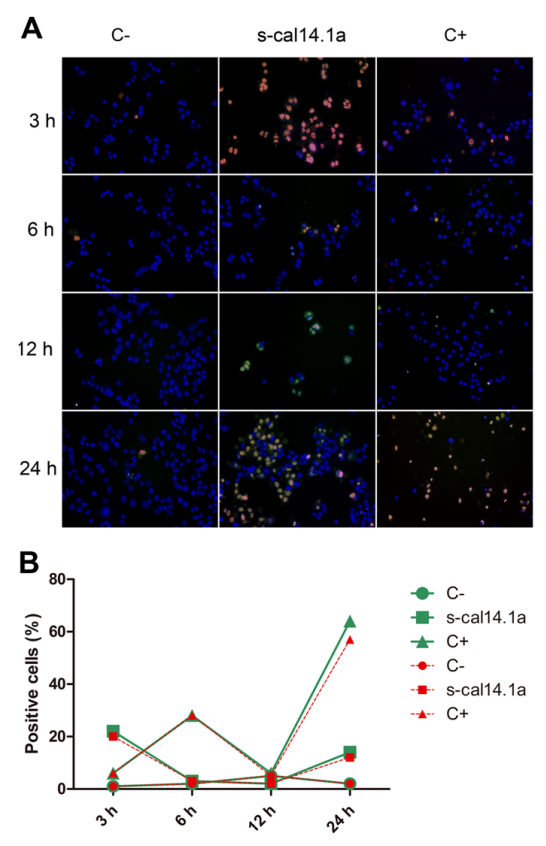

Figure 4. Time course of caspase- 3 and -7 activation in H1437 cell line. Cells were treated with $27 \mu \mathrm{M}$ of s-cal14.1a for 3, 6, 12 and $24 \mathrm{~h}$. (A) Representative image showing untreated cells (C-) and cells treated with s-cal14.1a and C+ (staurosporine $1 \mu \mathrm{M}$ ) at $460 \times$ overall magnification; (B) Graph showing counting positive cells to caspase- 3 and -7 activation. Cells stained blue were considered as $100 \%$. Results were expressed as the percentage of cells that are positive to caspase- 3 and -7 (green) and PI (red).

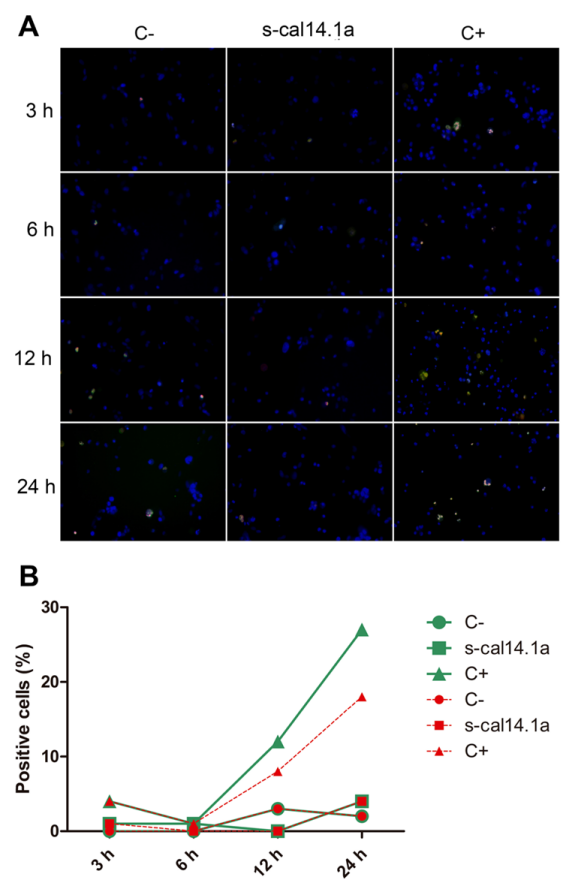

Figure 5. Time course of caspase-3/7 activation in H1975 cell line. (A) Representative image showing untreated cells $(\mathrm{C}-)$ and cells treated with s-cal14.1a and $\mathrm{C}+(1 \mu \mathrm{M}$ staurosporine $)$ at $460 \times$ overall magnification; (B) Graph showing counting positive cells to caspase-3 and -7 activation. Cells stained blue were considered as $100 \%$. Results were expressed as the percentage of cells that are positive to caspase-3 and -7 (green) and PI (red). 

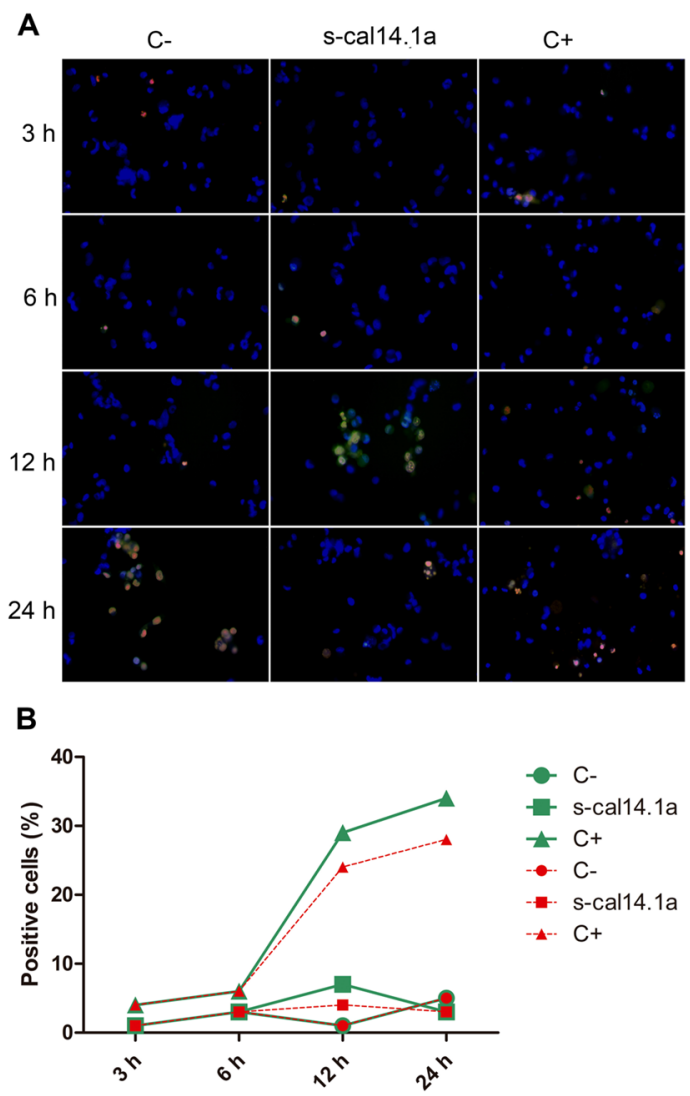

Figure 6. Time course of caspase-3/7 activation in H661 cell line. (A) Representative image showing untreated cells $(\mathrm{C}-)$ and cells treated with s-cal14.1a and $\mathrm{C}+(1 \mu \mathrm{M}$ staurosporine $)$ at $460 \times$ overall magnification; (B) Graph showing the number of positive cells to caspase-3 and -7 activation. Cells stained blue were considered as $100 \%$. Results were expressed as the percentage of cells that are positive to caspase-3 and -7 (green) and PI (red).

\subsection{Apoptosis-Dependent Cell Death Induced by s-cal14.1a on H1437}

These results indicate that s-cal14.1a induces cell death of lung cancer cell lines (up to 30\% decrease of survival). To demonstrate that cell death is caused by apoptosis we used small molecule inhibitors of apoptosis and necroptosis. z-VAD-fmk (carboenzoxy-valyl-alanyl-aspartyl-[O-methyl]fluorometylketone) is a cell-permeable pan-caspase inhibitor that irreversibly binds to the catalytic site of these proteases to inhibit activation and execution of apoptosis [40]. To inhibit necroptosis, necrosulfonamide (NSA) was used, a highly specific inhibitor that targets the Mixed Lineage Kinase domain-Like protein (MLKL), a critical component of the necroptotic pathway [41].

We studied the effect of these two inhibitors on cell death caused by s-cal14.1a in the cell line H1437 was analyzed (Figure 7). We decided to use only H1437 for this assay because its results in apoptosis-related genes expression and capase- 3 and -7 activation experiments. H1437 cells were treated with $27 \mu \mathrm{M}$ s-cal14.1a, $5 \mu \mathrm{M}$ staurosporine $(\mathrm{C}+)$ or preincubated for $1 \mathrm{~h}$ with $50 \mu \mathrm{M}$ NSA or (Z-VAD) then treated with s-cal14.1a. After $24 \mathrm{~h}$ of incubation, viability was determined with MTS assay.

The result shows that s-cal14.1a decreased the survival rate to less than $50 \%$ and the same was observed for the C+. Cells preincubated with NSA and s-cal14.a survived to the same extent as those treated with s-cal14.1a only. NSA fails to inhibit cell death suggesting that cell death induced by $\mathrm{s}$-cal14.1a is a necroptosis-independent event. On the contrary, cells pretreated with Z-VAD prior to s-cal14.1a addition survived as much as the non-treated cells. 


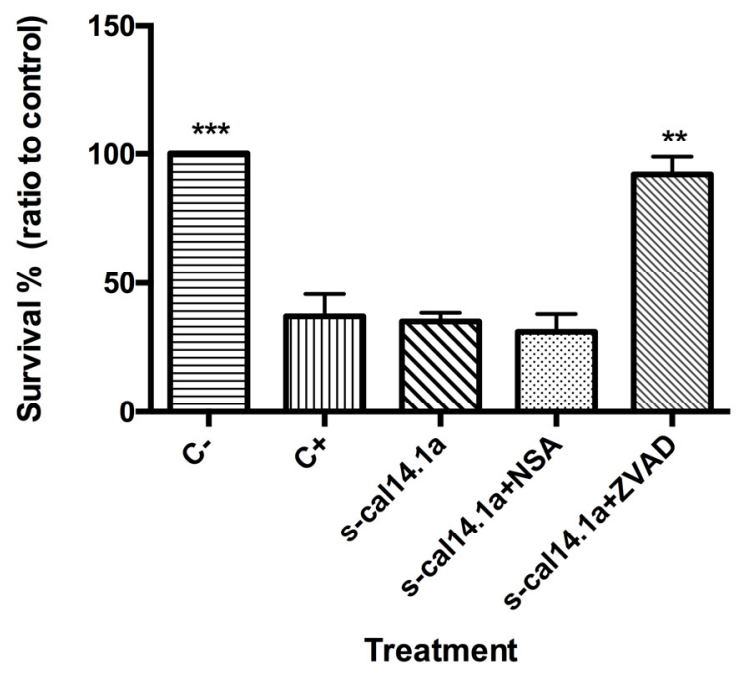

Figure 7. Cell death in H1437 cell line. Cells were seeded on 96-well plates and treated with $27 \mu \mathrm{M}$ of s-cal14.1a only and s-cal14.1a plus $50 \mu \mathrm{M}$ NSA (necrosulfonamide) or ZVAD (z-VAD-fmk). Survival was determined with MTS assay. Results were normalized to $C$ - (untreated cells) and are expressed as the mean \pm SEM. Positive control $(C+) 5 \mu \mathrm{M}$ of staurosporine. Experiments were done in triplicates. ** $p<0.01$ and ${ }^{* * *} p<0.001$ vs. s-cal14.1a treatment (unpaired $t$ Student's test).

\section{Discussion}

\subsection{Cytotoxic Effect of s-cal14.1a on Four Lung Cancer Cell Lines}

$\alpha$-conotoxins are small peptides (12-20 amino acid residues) isolated form the venom of cone snails and are known to target muscle- and neuronal-type nAChRs. $\alpha$-conotoxins are among the smallest conopeptides isolated from Conus sp. These toxins bind at the acetylcholine binding site in the nAChR acting as competitive antagonists [42]. In this work we analyzed the effect of s-cal14.1a on cell viability, this synthetic peptide has been characterized to target nAChRs [25]. The amino acid sequence and the cysteine pattern in s-cal14.1a are highly conserved in other Conus toxins that are active in nAChR, like the peptide It14a from Conus litteratus [43]. In lung cells nAChRs act as central mediators in the activation of pathways that promote growth, progression, and metastasis of tumors. nAChRs also regulate a network of stimulatory and inhibitory neurotransmitters that govern the synthesis and release of growth, angiogenic, and neurogenic factors in the microenvironment of cancer cells and in distant organs [2,29]. Therefore, blocking signaling cascades downstream of nAChRs with antagonists may result in cell death [1]. Expression of nAChRs subunits such as $\alpha 2, \alpha 3, \alpha 4, \alpha 5, \alpha 6, \alpha 7$, $\alpha 9, \beta 2$, and $\beta 4$ has been detected in lung cancer while overexpression is directly related to lung cancer pathogenesis and resistance $[2,3,44,45]$. We determined the mRNA levels of expression of nAChR subunits in a panel of lung cancer cell lines, H1299, H1437, H1975 and H661 (Figure S2A-D). All cell lines tested expressed $\alpha 5 ; \mathrm{H} 1299$ (Figure S2A) and H1437 (Figure S2B) also express minor levels of $\alpha 7$. H661 expresses $\alpha 3, \alpha 7$ and $\alpha 9$ as well (Figure S2D). Since the lung cancer cells studied express nAChR subunits we hypothesize that s-cal14.1a may target nAChRs and block signaling downstream.

By treating different cancer cell lines with s-cal14.1a we discovered a cytotoxic effect. Some of the cell lines showed a reduction in cell viability of up to $40 \%$ (Figure 1); we speculate that s-cal14.1a may target $\mathrm{nAChRs}$ thus blocking the signaling cascade, resulting in cell death. Signaling through $\mathrm{nAChRs}$ begins with binding of agonists such as ACh (acetylcholine), nicotine and tobacco nitrosamines, causing a conformational change that leads to channel opening and influx of $\mathrm{Na}^{+}$and $\mathrm{Ca}^{2+}$, and efflux of $\mathrm{K}^{+}$. Resulting membrane depolarization opens voltage-operated calcium channels, leading to additional flow of $\mathrm{Ca}^{2+} . \mathrm{Ca}^{2+}$ influx triggers secretion of mitogenic factors and activates signaling cascades involved in cell proliferation, apoptotic inhibition, migration and angiogenesis $[1,29,46]$. Blocking $\mathrm{nAChR}$ channels with an antagonist such as s-cal14.1a could prevent downstream signaling 
resulting in inhibition of, proliferation, migration, and angiogenesis, and apoptosis. A study focusing on antagonists that target $\mathrm{nAChRs}$ as a therapeutic alternative to treat cancer has provided significant insights into their mechanisms of action [29]. Among these nAChRs, the $\alpha 7-n A C h R$ subunits are known to be overexpressed in lung cancer; in vitro experiments suggest that malignant growth can be halted using $\alpha$-conotoxins, which are competitive antagonists of $n A C h R s$ [47]. Alternatively, the exquisite specificity of toxins has been used to target receptors for drug delivery purposes. The $\alpha$-conotoxin ImI was used as a targeting peptide to efficiently deliver the chemotherapeutic agent paclitaxel to the $\alpha 7-n A C h R$ to tumor cells in breast cancer [48]. nAChRs are believed to play an important role in nicotine-related lung cancer pathogenesis [49]. Although nicotine itself is not a carcinogen, it is the principal reinforcing component in cigarette smoke and can promote tumor growth by inducing proliferation, angiogenesis, migration and invasion [50].

A previous study demonstrated that exposure to nicotine and its derivatives, which bind to nAChRs on bronchial epithelial cells, can regulate proliferation and apoptosis of non-small cell lung cancer (NSCLC) by activating the Akt pathway [51,52]. In particular, $\alpha 5-n A C h R$ has been found to be closely associated with lung cancer risk and nicotine dependence. It has been reported that nicotine interacts with $\alpha 5-\mathrm{nAChR}$ on the surface of A549 cells leading to activation the ERK and Akt signaling, upregulation of VEGF levels and HIF-1 $\alpha$ signaling. Ultimately, this promotes cell proliferation, angiogenesis, and invasion [2]. nAChRs have also been noted to promote a nicotine-stimulated epithelial-to-mesenchymal transition (EMT) in a variety of human cancer cell lines, especially in small cell lung cancer and non-small cell lung cancer [53].

It has been demonstrated that $\alpha 9-\mathrm{nAChR}$ is a key molecule in mediating the nicotine-enhanced migration of breast cancer cells through regulation of EMT markers, while pretreatment with a nAChR inhibitors abolishes these effects $[47,54]$. nAChRs are important therapeutic targets, and development of new antagonists that specifically block these targets are potentials candidates for alternative cancer therapy.

Based on the above studies, we propose that s-cal14.1a may induce cell death by acting on the nAChRs expressed in lung cancer cells and may be an alternative approach to design novel therapeutic compounds. Synthetic peptides based on native sequence of conotoxins can be also used as tools for nAChR characterization.

\subsection{Apoptosis-Related Genes as Regulators of Cell Death}

Apoptosis is a process by which damaged, unattached, mutant and aged cells are eliminated, aberrations in this pathway can lead to a variety of diseases including cancer $[55,56]$. Targeting components of the apoptotic pathway as a therapeutic approach in cancer is supported by the finding that aberrant apoptosis is central to tumor growth and progression. Indeed, suppression of apoptosis is a recognized hallmark of cancer [57]. Novel approaches to activate the apoptotic pathway may result in induction of death in cancerous cells. Overexpression of anti-apoptotic Bcl-2 family members is known to cause apoptosis or therapy resistance in a wide range of tumors. Development of therapies that target these modulators of apoptosis appears to be a promising approach [58,59].

$\mathrm{NF}_{\kappa} \mathrm{B}$ family is a central mediator of immune, inflammatory, stress responses, apoptosis and cell proliferation. NFKB is constitutively activated in a variety of leukemia and solid tumors, including lung cancer and plays a critical role in promoting the survival and growth of tumor cells [37,60,61]. COX-2 is an inducible form of cyclooxygenase that represents a potential pharmacologic target to prevent and treat a variety of malignancies [62]. Overexpression of COX-2 has been shown in various cancer types and has been linked with shorter survival of patients with lung caner [63].

We evaluated the role of a synthetic peptide s-cal14.1a, in human lung cancer cell lines. s-cal14.1a had a cytotoxic effect on four different cell lines, decreasing the cell viability by $40 \%$. In order to elucidate how some genes involved in apoptosis regulation are expressed in H1299, H1437, H1975 and H661 lung cancer cells after treatment with s-cal14.1a, the expression of apoptotic-related genes were determined and the induction of caspase- 3 and -7 activation was analyzed. 
This study demonstrates that s-cal14.1a induces cell death of lung cancer cell lines, gene expression levels of proteins involved in regulating and executing apoptosis reveal an interesting pattern for Bcl-2 and BAX mRNA levels (Figure 2A-D). In all cell lines we detected down-regulation of BAX and up-regulation of Bcl-2, except in H1299 that showed 15-fold increase of BAX after treatment with s-cal14.1a. It has been reported that in human gastric adenocarcinoma BAX expression is significantly down-regulated during the first $24 \mathrm{~h}$ of treatment with etoposide, cisplatin or taxol, however levels gradually increased in the next 48 and $72 \mathrm{~h}$ [17]. Another work showed that the antineoplastic drug 5-FU decreased the mRNA levels of Bcl-2 in the first $48 \mathrm{~h}$, which coincided with the up-regulation of BAX, after $72 \mathrm{~h}$ of treatment Bcl-2 was up-regulated and the levels of BAX were decreased in human gastric adenocarcinoma [64]. Extended time lapse-treatment and dose-dependent analysis of cells treated with s-cal14.1a may reveal a different expression pattern for Bcl-2 and BAX. The data presented here may be the result of a cytotoxic effect independent of Bcl-2 and BAX.

Expression of NFkB-1 in H1299 cells (Figure 2A) was considerably increased after treatment with s-cal14.1a. H1437 and H1975 cells (Figure 2B,C) showed down-regulation of NFkB-1 after the treatment with s-cal14.1a. In the three cell lines, staurosporine, an activator of apoptosis, showed the same expression pattern observed in cells treated with s-cal14.1a. Expression of COX-2 (Figure 2D) does not reveal significant differences. These results indicate that most likely s-cal14.1a promotes cell death via an NFKB-1-dependent pathway. Under certain conditions, NFkB can promote or amplify cell death, however most of these effects relate to the extrinsic pathway, including expression of genes that code for the death receptor Fas or its ligand FasL [61]. Almeida et al. (2014) report that cisplatin-resistant cells have active NFKB signaling and inhibition of NFKB translocation to the nucleus enhances apoptosis in head and neck squamous cell carcinoma [65]. Targeting NFKB is a potential therapeutic approach to overcome chemoresistance and radioresistance for cancer treatment [66].

\subsection{Activation of Caspase -3 and -7 and Apoptosis by s-cal14.1a}

Caspases are a family of proteins that maintain homeostasis by regulating cell death and inflammation, they perform these functions by means of limited proteolytic cleavage in specific aspartate residue of their substrates $[67,68]$. The caspase gene family can be divided into two functional subgroups based on their roles; inflammatory caspases (caspase-1, -4 , and -5 ) regulate cytokine maturation and inflammatory responses. Apoptotic caspases are further divided into two functional subgroups, initiator of apoptosis caspases (caspase-2, -8, -9, and -10) and effector caspases (caspase-3, -6, and -7) [69-71]. In this work, activation of caspase-3 and -7 induced by s-cal14.1a was analyzed using the commercial kit CellEvent ${ }^{\mathrm{TM}}$ Caspase-3/7 Green Detection Reagent. Treatment of H1299, H1437, H1974 and H661 cancer cell lines was performed with s-cal14.1a for 3, 6, 12 and $24 \mathrm{~h}$. H1299 cells treated with cal14.a showed caspase -3 and -7 activation in up to $40 \%$ of cells analyzed at $12 \mathrm{~h}$ of incubation (Figure 3A,B), staurosporine induced caspase activation only in $20 \%$ of the cells at $24 \mathrm{~h}$. Cell line H1437 (Figure 4A,B) underwent considerable activation of caspase-3 and -7 (20\%) at $3 \mathrm{~h}$ and $24 \mathrm{~h}$ of incubation, while treatment with staurosporine showed caspase activation in $60 \%$ of the cells after $24 \mathrm{~h}$. These results indicate that maximum activation of caspase- 3 and -7 is reached between 6 and $12 \mathrm{~h}$ of treatment. It is known that the basic mitochondrial pathway of apoptosis, from the initial trigger to destruction of the cell, can take hours or even days. However, the events that lead to caspase activation often take about ten minutes. This can occur at any time following the induction of apoptosis by a death signal [72]. Nevertheless, in HL60 cells incubation with TNF- $\alpha / \mathrm{CHX}$ (tumor necrosis factor- $\alpha$ and cycloheximide), $50 \%$ of the cells undergo apoptosis during the initial $6 \mathrm{~h}$. In HUVECs cells the same treatment leads to apoptotic death during the first $18 \mathrm{~h}$ of incubation [39]. The response of H1975 and H661 cells treated with s-cal14.1a (Figures 5A,B and 6A,B) had no relevant outcome, neither of cell lines showed a significant caspase activation. H1975 and H661 cells treated with staurosporine had $30 \%$ and $40 \%$ of positive cells, respectively. H1975 and H661 cells may be insensitive to s-cal14.1a or may need higher doses of s-cal14.1a or extended incubation. 
Caspase- 3 is the main executioner of apoptosis and can be activated through both extrinsic and intrinsic signaling pathway [23]. There is evidence that loss of expression or function of caspase-3 can render breast cancer cells resistant to apoptosis. These findings may have important clinical implications, not only as disease marker, but also as therapeutic target for different types of cancer [73]. This may explain the lack of caspase activity in untreated lung cancer cells $(\mathrm{C}-$ ). They showed less than $20 \%$ of positive cells (Figures 3-6). We demonstrate that caspase activity was increased after treatment with s-cal14.1a. Thus, s-cal14.1a could be considered as potential apoptosis activator in lung cancer. Caspase- 3 has been shown to interfere with NFKB activation, in this case, caspase- 3 cleaves $\mathrm{I} \kappa \mathrm{B} \alpha$ generating a cleavage fragment that potentially acts as a constitutive inhibitor of NFKB [74]. It was also reported, that proteolysis by caspase inactivate NFKB proteins and transform them into dominant negative factors, still capable of DNA binding but without its transactivation potential [61]. This may explain the reduced expression levels of NFKB-1 and the activation of caspase- 3 and -7 in H1437 after the treatment with s-cal14.1a. The fact that s-cal14.1a plus ZVAD cause an inhibition of cell death, support our previous findings that s-cal14.1a induces apoptosis, a process dependent of caspase activity. These data provide us a promising pathway for s-cal14.1a on H1437 cell-death. However, further research is needed to explain details the mechanism of action of s-cal14.1a.

\section{Materials and Methods}

\subsection{Cancer Cell Lines}

Human non-small cell lung cancer H1299 (carcinoma), H1437 (adenocarcinoma), H1975 (adenocarcinoma) and H661 (large cell carcinoma) were cultured at $37{ }^{\circ} \mathrm{C}$ with $5 \% \mathrm{CO}_{2}$ in RMPI-1640 supplemented with $10 \% v / v$ fetal bovine serum (FBS heat inactivated from Sigma-Aldrich, St. Louis, MO, USA) and $1 \%$ antibiotic-antimycotic (10,000 units penicilin, $10 \mathrm{mg}$ sterptomycin, and $25 \mathrm{mg} / \mathrm{mL}$ amphotericin B per mL, Sigma-Aldrich). All cell lines were acquired from IECSA (México D.F., México).

\subsection{Cell Viability Assay}

Cell viability was determined using the CellTiter 96 Aqueous One Solution Cell Proliferation Assay Kit MTS (Promega, Madison, WI, USA). The MTS assay is based on the conversion of a tetrazolium salt into a colored, aqueous soluble formazan product by dehydrogenase enzymes in metabolically active cells. The amount of formazan produced is directly proportional to the number of living cells in culture. Two hundred fifty thousand cells per two hundred milliliter were seeded in triplicate in 96-well plates and were treated with cal14.1a $(27 \mu \mathrm{M})$ and $\mathrm{C}+(5 \mu \mathrm{M})$ for $24 \mathrm{~h}$. Twenty microliters (3-(4,5-dimethylthiazol-2-yl)-5-(3-carboxymethoxyphenyl)-2-(4-sulfophenyl)-2H-tetrazolium, inner salt (MTS)) were added, and the amount of formazan converted by viable cells was determined by measuring absorbance at $490 \mathrm{~nm}$ on a 96-well microplate reader EPOCH (BioTek, Winooski, VT, USA). Results are expressed as the percentage of treated to untreated cells.

\subsection{RNA Extraction and Quantitative Real-Time PCR (RT-qPCR) Analysis}

Total RNA was isolated using Tri Reagent ${ }^{\circledR}$ (Sigma-Aldrich) and quantified by NanoDrop ${ }^{\text {TM }}$ Lite Spectrophotometer (Thermo Scientific, Waltham, MA, USA). Two micrograms of RNA were reverse transcribed using a mix of oligodT $\mathrm{T}_{20} /$ random hexamers in the Superscript III cDNA synthesis kit (Invitrogen, Waltham, MA, USA), according to manufacturer's instructions. Real time PCR reactions were performed using SybrGreen master mix in a 7500 real time PCR system (Applied Biosystems, Waltham, MA, USA). Primer sets specifics for the mature coding sequence of each gene were designed using BLAST (NIH, Bethesda, MD, USA). Forward and reverse primers were designed from the $m R N A$ sequence (GenBank Accession enlisted in Table 1). To calculate the changes in mRNA expression, we first normalized mRNA expression of target gene to the $\beta$-actin mRNA expression in a given sample; the mRNA expression for each gene in the experimental treatment was compared with the level of 
mRNA expression in the non-treated cells. Fold changes in the mRNA expression are expressed as the mean $\pm \mathrm{SD}$ relative to the negative control (untreated cells).

Table 1. Primers sequences and GenBank accession number used for RT-qPCR.

\begin{tabular}{ccc}
\hline Gene & \multicolumn{1}{c}{ Primer } & Genbank Accession Number and Reference \\
\hline \multirow{2}{*}{$\begin{array}{c}\text { F-actin } \\
\text { Rel-2 }\end{array}$} & $\begin{array}{r}\text { F: ATGTGTGTGGAGAGCGTCACC } \\
\text { R: TGAGCAGAGTCTTCAGAGACAGCC }\end{array}$ & BRWS1 \\
\hline \multirow{2}{*}{ BAX } & $\begin{array}{r}\text { F: TGGCAGCTGACATGTTTTCTGAC } \\
\text { R: TCACCCAACCACCCRGGTCTT }\end{array}$ & BC027258.1 \\
\hline \multirow{2}{*}{ NFkB-1 } & $\begin{array}{r}\text { F: CGCCGCTTAGGAGGGAGA } \\
\text { R: AGGTATGGGCCATCTGCTGT }\end{array}$ & NM_004324.3 \\
\hline \multirow{2}{*}{ COX-2 } & $\begin{array}{l}\text { F: TGCATTCTTTGCCCCAGCACT } \\
\text { R: AAAGGCGCAGTTTACGCTGT }\end{array}$ & NM_003998.3 \\
\hline
\end{tabular}

\subsection{Caspase-3 and -7 Activity Assay}

Intracellular caspase-3 and-7 activity was quantified by fluorescence microscopy using the CellEvent ${ }^{\mathrm{TM}}$ Caspase-3/7 Green Detection Reagent (Life Technologies, Waltham, MA, USA). Cells were seeded in 96-well plates (Corning) after 3, 6, 12 and $24 \mathrm{~h}$ of cal14.1a (27 $\mu \mathrm{M})$ and $\mathrm{C}+$ (staurosporine, $1 \mu \mathrm{M})$ treatment. Plates were treated with $5 \mu \mathrm{M}$ of CellEvent ${ }^{\mathrm{TM}}$ Caspase-3/7 Green Detection Reagent (Life Technologies) this kit relies on the cleavage of the tetrapeptide substrate DEVD conjugated to a quenched fluorophore. $10 \mu \mathrm{g} / \mathrm{mL}$ of Hoechst 33342 (Life technologies) and $50 \mu \mathrm{g} / \mathrm{mL}$ of propidium iodide (PI) (Sigma-Aldrich) were used as reference for nucleus staining. The plates were incubated for $30 \mathrm{~m}$ at $37{ }^{\circ} \mathrm{C}$ with $5 \% \mathrm{CO}_{2}$ and exposed to corresponding filter (blue channel: 390-40/446-33 nm, green channel: 482-18/532-59 $\mathrm{nm}$ and red channel: 586-15/646-68 nm) on the fluorescence microscope.

\subsection{Cell Imaging}

Cell images were obtained with an inverted microscope EVOS FLoid Cell Imaging Station (Life technologies) at $20 \times$ magnification. Each image was edited on a computer using ImageJ.

\subsection{Statistic Analysis}

All data were analyzed under GraphPad Prism5 software (La Jolla, CA, USA). Student $t$ test was applied for comparing differences among treatments. A $p$ value $\leqslant 0.05$ was considerate statistically significant.

\section{Conclusions}

To the best of our knowledge, this study demonstrates that a novel synthetic peptide s-cal14.1a induces apoptosis via caspase- 3 and -7 activation in lung cancer cell lines. This information elucidates an alternative study and treatment for lung cancer cells. The possibility to develop agents that directly target apoptotic mechanisms has generated excitement and could lead to more effective therapies with less toxic side effects.

Supplementary Materials: The following are available online at www.mdpi.com/2072-6651/8/2/38/s1.

Acknowledgments: This work was supported by the National Council of Science and Technology of Mexico (CONACyT).

Author Contributions: Conceived and designed the experiments: I.O.-P., M.N., K.E.C.-L., C.Á.-D. and A.F.L.-N. Performed the experiments and analyzed the data: I.O.-P., C.Á.-D. and K.E.C.-L. Contributed with reagents: M.N., 
L.N.S.-C., G.S. and A.F.L.-N. Contributed with manuscript revision: M.N., G.S., K.E.C.-L. and A.F.L.-N. Wrote the paper: I.O.-P.

Conflicts of Interest: The authors declare no conflict of interest.

\section{Abbreviations}

The following abbreviations are used in this manuscript:

$\begin{array}{ll}\text { nAChRs } & \text { acetylcholine nicotinic receptors } \\ \text { ACh } & \text { acetylcholine } \\ \text { PI } & \text { propidium iodide } \\ \text { NSCLC } & \text { non-small cell lung cancer } \\ \text { EMT } & \text { epithelial-to-mesenchymal transition } \\ \text { TNF- } \alpha / \text { CHX } & \text { tumor necrosis factor- } \alpha \text { and cycloheximide }\end{array}$

\section{References}

1. Improgo, M.R.; Tapper, A.R.; Gardner, P.D. Nicotinic acetylcholine receptor-mediated mechanisms in lung cancer. Biochem. Pharmacol. 2011, 82, 1015-1021. [CrossRef] [PubMed]

2. Ma, X.; Jia, Y.; Zu, S.; Li, R.; Jia, Y.; Zhao, Y.; Xiao, D.; Dang, N.; Wang, Y. Alpha5 nicotinic acetylcholine receptor mediates nicotine-induced HIF-1 $\alpha$ and VEGF expression in non-small cell lung cancer. Toxicol. Appl. Pharmacol. 2014, 278, 172-179. [CrossRef] [PubMed]

3. Reina Improgo, M.; Soll, L.G.; Tapper, A.R.; Gardner, P.D. Nicotinic acetylcholine receptors mediate lung cancer growth. Front. Physiol. 2013, 4, 1-6.

4. Zhang, H.; Zhang, C.; Wu, D. Activation of insulin-like growth factor 1 receptor regulates the radiation-induced lung cancer cell apoptosis. Immunobiology 2015, 220, 1136-1140. [CrossRef] [PubMed]

5. Haque, A.; Rahman, M.A.; Fuchs, J.R.; Chen, Z.G.; Khuri, F.R.; Shin, D.M.; Amin, A.R. FLLL12 induces apoptosis in lung cancer cells through a p53/p73-independent but death receptor 5-dependent pathway. Cancer Lett. 2015, 363, 166-175. [CrossRef] [PubMed]

6. Franklin, J.B.; Rajesh, R.P. A sleep-inducing peptide from the venom of the Indian cone snail Conus araneosus. Toxicon 2015, 103, 39-47. [CrossRef] [PubMed]

7. Akondi, K.B.; Muttenthaler, M.; Dutertre, S.; Kaas, Q.; Craik, D.J.; Lewis, R.J.; Alewood, P.F. Discovery, synthesis, and structure-activity relationships of conotoxins. Chem. Rev. 2014, 114, 5815-5847. [CrossRef] [PubMed]

8. Olivera, B.M. Conus venom peptides: Correlating chemistry and behavior. J. Comp. Physiol. A Sens. Neural Behav. Physiol. 1999, 185, 353-359. [CrossRef]

9. Wang, C.; Chi, C. Conus peptides-A rich pharmaceutical treasure the biology of cone snails classification and nomenclature of Conus peptides. Acta Biochim. Biophys. Sin. (Shanghai) 2004, 36, 713-723. [CrossRef] [PubMed]

10. Zhou, M.; Wang, L.; Wu, Y.; Zhu, X.; Feng, Y.; Chen, Z.; Li, Y.; Sun, D.; Ren, Z.; Xu, A. Characterizing the evolution and functions of the M-superfamily conotoxins. Toxicon 2013, 76, 150-159. [CrossRef] [PubMed]

11. Terlau, H.; Olivera, B.M. Conus venoms: A rich source of novel ion channel-targeted peptides. Physiol. Rev. 2004, 84, 41-68. [CrossRef] [PubMed]

12. Kaas, Q.; Yu, R.; Jin, A.H.; Dutertre, S.; Craik, D.J. ConoServer: Updated content, knowledge, and discovery tools in the conopeptide database. Nucleic Acids Res. 2012, 40, 325-330. [CrossRef] [PubMed]

13. Chen, P.; Garrett, J.E.; Watkins, M.; Olivera, B.M. Purification and characterization of a novel excitatory peptide from Conus distans venom that defines a novel gene superfamily of conotoxins. Toxicon 2008, 52, 139-145. [CrossRef] [PubMed]

14. Aguilar, M.B.; Ortiz, E.; Kaas, Q.; López-Vera, E.; Becerril, B.; Possani, L.D.; De La Cotera, E.P.H. Precursor De13.1 from Conus delessertii defines the novel G gene superfamily. Peptides 2013, 41, 17-20. [CrossRef] [PubMed]

15. Reed, J.C. Mechanisms of apoptosis. Am. J. Pathol. 2000, 157, 1415-1430. [CrossRef] 
16. Oliver, L.; Vallette, F.M. The role of caspases in cell death and differentiation. Drug Resist. Updat. 2005, 8, 163-170. [CrossRef] [PubMed]

17. Korbakis, D.; Scorilas, A. Quantitative expression analysis of the apoptosis-related genes BCL2, BAX and BCL2L12 in gastric adenocarcinoma cells following treatment with the anticancer drugs cisplatin, etoposide and taxol. Tumor Biol. 2012, 33, 865-875. [CrossRef] [PubMed]

18. Gupta, S.; Kass, G.E.N.; Szegezdi, E.; Joseph, B. The mitochondrial death pathway: A promising therapeutic target in diseases. J. Cell. Mol. Med. 2009, 13, 1004-1033. [CrossRef] [PubMed]

19. Kroemer, G. Mitochondrial control of apoptosis: An introduction. Biochem. Biophys. Res. Commun. 2003, 304, 433-435. [CrossRef]

20. Ozören, N.; El-Deiry, W.S. Cell surface death receptor signaling in normal and cancer cells. Semin. Cancer Biol. 2003, 13, 135-147. [CrossRef]

21. Thorburn, A. Death receptor-induced cell killing. Cell. Signal. 2004, 16, 139-144. [CrossRef] [PubMed]

22. Pore, M.M.; Hiltermann, T.J.; Kruyt, F.A. Targeting apoptosis pathways in lung cancer. Cancer Lett. 2013, 332, 359-368. [CrossRef] [PubMed]

23. Ghavami, S.; Hashemi, M.; Ande, S.R.; Yeganeh, B.; Xiao, W.; Eshraghi, M.; Bus, C.J.; Kadkhoda, K.; Wiechec, E.; Halayko, A.J.; et al. Apoptosis and cancer: Mutations within caspase genes. J. Med. Genet. 2009, 46, 497-510. [CrossRef] [PubMed]

24. Zheng, L.; Lin, X.; Wu, N.; Liu, M.; Zheng, Y.; Sheng, J.; Ji, X.; Sun, M. Targeting cellular apoptotic pathway with peptides from marine organisms. Biochim. Biophys. Acta Rev. Cancer 2013, 1836, 42-48. [CrossRef] [PubMed]

25. Biggs, J.S.; Watkins, M.; Puillandre, N.; Ownby, J.P.; Lopez-Vera, E.; Christensen, S.; Moreno, K.J.; Bernaldez, J.; Licea-Navarro, A.; Corneli, P.S.; et al. Evolution of Conus peptide toxins: Analysis of Conus californicus Reeve, 1844. Mol. Phylogenet. Evol. 2010, 56, 1-12. [CrossRef] [PubMed]

26. Lluisma, A.O.; Milash, B.A.; Moore, B.; Olivera, B.M.; Bandyopadhyay, P.K. Novel venom peptides from the cone snail Conus pulicarius discovered through next-generation sequencing of its venom duct transcriptome. Mar. Genomics 2012, 5, 43-51. [CrossRef] [PubMed]

27. Dowell, C.; Olivera, B.M.; Garrett, J.E.; Staheli, S.T.; Watkins, M.; Kuryatov, A.; Yoshikami, D.; Lindstrom, J.M.; McIntosh, J.M. Alpha-conotoxin PIA is selective for alpha6 subunit-containing nicotinic acetylcholine receptors. J. Neurosci. 2003, 23, 8445-8452. [PubMed]

28. Pucci, L.; Grazioso, G.; Dallanoce, C.; Rizzi, L.; De Micheli, C.; Clementi, F.; Bertrand, S.; Bertrand, D.; Longhi, R.; De Amici, M.; et al. Engineering of $\alpha$-conotoxin MII-derived peptides with increased selectivity for native $\alpha 6 \beta 2^{*}$ nicotinic acetylcholine receptors. FASEB J. 2011, 25, 3775-3789. [CrossRef] [PubMed]

29. Schuller, H.M. Is cancer triggered by altered signalling of nicotinic acetylcholine receptors? Nat. Rev. Cancer 2009, 9, 195-205. [CrossRef] [PubMed]

30. Guo, L.; Li, L.; Wang, W.; Pan, Z.; Zhou, Q.; Wu, Z. Mitochondrial reactive oxygen species mediates nicotine-induced hypoxia-inducible factor- $1 \alpha$ expression in human non-small cell lung cancer cells. Biochim. Biophys. Acta 2012, 1822, 852-861. [CrossRef] [PubMed]

31. Warren, G.W.; Romano, M.A.; Kudrimoti, M.R.; Randall, M.E.; McGarry, R.C.; Singh, A.K.; Rangnekar, V.M. Nicotinic modulation of therapeutic response in vitro and in vivo. Int. J. Cancer 2012, 131, 2519-2527. [CrossRef] [PubMed]

32. Malich, G.; Markovic, B.; Winder, C. The sensitivity and specificity of the MTS tetrazolium assay for detecting the in vitro cytotoxicity of 20 chemicals using human cell lines. Toxicology 1997, 124, 179-192. [CrossRef]

33. Yadav, S.S.; Prasad, C.B.; Prasad, S.B.; Pandey, L.K.; Singh, S.; Pradhan, S.; Narayan, G. Anti-tumor activity of staurosporine in the tumor microenvironment of cervical cancer: An in vitro study. Life Sci. 2015, 133, 21-28. [CrossRef] [PubMed]

34. Skrzypski, M. Quantitative reverse transcriptase real-time polymerase chain reaction (qRT-PCR) in translational oncology: Lung cancer perspective. Lung Cancer 2008, 59, 147-154. [CrossRef] [PubMed]

35. Paul-Samojedny, M.; Kokocińska, D.; Samojedny, A.; Mazurek, U.; Partyka, R.; Lorenz, Z.; Wilczok, T. Expression of cell survival/death genes: Bcl-2 and Bax at the rate of colon cancer prognosis. Biochim. Biophys. Acta Mol. Basis Dis. 2005, 1741, 25-29. [CrossRef] [PubMed]

36. Akl, H.; Vervloessem, T.; Kiviluoto, S.; Bittremieux, M.; Parys, J.B.; De Smedt, H.; Bultynck, G. A dual role for the anti-apoptotic Bcl-2 protein in cancer: Mitochondria versus endoplasmic reticulum. Biochim. Biophys. Acta Mol. Cell Res. 2014, 1843, 2240-2252. [CrossRef] [PubMed] 
37. Chai, S.; Qian, Y.; Tang, J.; Liang, Z.; Zhang, M.; Si, J.; Li, X.; Huang, W.; Xu, R.; Wang, K. $\mathrm{Ca} 2+/$ calmodulin-dependent protein kinase II $\gamma$, a critical mediator of the NF-kB network, is a novel therapeutic target in non-small cell lung cancer. Cancer Lett. 2014, 344, 119-128. [CrossRef] [PubMed]

38. Walsh, J.G.; Cullen, S.P.; Sheridan, C.; Lüthi, A.U.; Gerner, C.; Martin, S.J. Executioner caspase-3 and caspase-7 are functionally distinct proteases. Proc. Natl. Acad. Sci. USA 2008, 105, 12815-12819. [CrossRef] [PubMed]

39. Wolbers, F.; Buijtenhuijs, P.; Haanen, C.; Vermes, I. Apoptotic cell death kinetics in vitro depend on the cell types and the inducers used. Apoptosis 2004, 9, 385-392. [CrossRef] [PubMed]

40. Van Noorden, C.J.F. Editorial: The history of Z-VAD-FMK, a tool for understanding the significance of caspase inhibition. Acta Histochem. 2001, 103, 241-251. [CrossRef] [PubMed]

41. Sun, L.; Wang, H.; Wang, Z.; Chen, S.; Liao, D.; Wang, L.; Yan, J.; Liu, W.; Lei, X.; Wang, X. Mixed lineage kinase domain-like protein mediates necrosis signaling downstream of RIP3 kinase. Cell 2012, 148, $213-227$. [CrossRef] [PubMed]

42. Lebbe, E.K. M.; Peigneur, S.; Maiti, M.; Mille, B.G.; Devi, P.; Ravichandran, S.; Lescrinier, E.; Waelkens, E.; D'Souza, L.; Herdewijn, P.; et al. Discovery of a new subclass of $\alpha$-conotoxins in the venom of Conus australis. Toxicon 2014, 91, 145-154. [CrossRef] [PubMed]

43. Peng, C.; Tang, S.; Pi, C.; Liu, J.; Wang, F.; Wang, L.; Zhou, W.; Xu, A. Discovery of a novel class of conotoxin from Conus litteratus, 1t14a, with a unique cysteine pattern. Peptides 2006, 27, 2174-2181. [CrossRef] [PubMed]

44. Lam, D.C.-L.; Girard, L.; Ramirez, R.; Chau, W.-S.; Suen, W.; Sheridan, S.; Tin, V.P.C.; Chung, L.; Wong, M.P.; Shay, J.W.; et al. Expression of nicotinic acetylcholine receptor subunit genes in non-small-cell lung cancer reveals differences between smokers and nonsmokers. Cancer Res. 2007, 67, 4638-4647. [CrossRef] [PubMed]

45. Tsurutani, J.; Castillo, S.S.; Brognard, J.; Granville, C.A.; Zhang, C.; Gills, J.J.; Sayyah, J.; Dennis, P.A. Tobacco components stimulate Akt-dependent proliferation and NFkB-dependent survival in lung cancer cells. Carcinogenesis 2005, 26, 1182-1195. [CrossRef] [PubMed]

46. Cattaneo, M.G.; Codignola, A.; Vicentini, L.M.; Clementi, F.; Sher, E. Nicotine stimulates a serotonergic autocrine loop in human small-cell lung carcinoma. Cancer Res. 1993, 53, 5566-5568. [PubMed]

47. Ho, Y.S.; Lee, C.H.; Wu, C.H. The alpha 9-nicotinic acetylcholine receptor serves as a molecular target for breast cancer therapy. J. Exp. Clin. Med. 2011, 3, 246-251. [CrossRef]

48. Mei, D.; Lin, Z.; Fu, J.; He, B.; Gao, W.; Ma, L.; Dai, W.; Zhang, H.; Wang, X.; Wang, J.; et al. The use of $\alpha$-conotoxin ImI to actualize the targeted delivery of paclitaxel micelles to $\alpha 7 \mathrm{nAChR}$-overexpressing breast cancer. Biomaterials 2015, 42, 52-65. [CrossRef] [PubMed]

49. Grando, S.A. Basic and clinical aspects of non-neuronal acetylcholine: Biological and clinical significance of non-canonical ligands of epithelial nicotinic acetylcholine receptors. J. Pharmacol. Sci. 2008, 106, 174-179. [CrossRef] [PubMed]

50. Warren, G.; Singh, A. Nicotine and lung cancer. J. Carcinog. 2013, 12, 1. [CrossRef] [PubMed]

51. Cardinale, A.; Nastrucci, C.; Cesario, A.; Russo, P. Nicotine: Specific role in angiogenesis, proliferation and apoptosis. Crit. Rev. Toxicol. 2012, 42, 68-89. [CrossRef] [PubMed]

52. Nakada, T.; Kiyotani, K.; Iwano, S.; Uno, T.; Yokohira, M.; Yamakawa, K.; Fujieda, M.; Saito, T.; Yamazaki, H.; Imaida, K.; et al. Lung tumorigenesis promoted by anti-apoptotic effects of cotinine, a nicotine metabolite through activation of PI3K/Akt pathway. J. Toxicol. Sci. 2012, 37, 555-563. [CrossRef] [PubMed]

53. Improgo, M.R. D.; Scofield, M.D.; Tapper, A.R.; Gardner, P.D. The nicotinic acetylcholine receptor CHRNA5/A3/B4 gene cluster: Dual role in nicotine addiction and lung cancer. Prog. Neurobiol. 2010, 92, 212-226. [CrossRef] [PubMed]

54. Hung, C.-S.; Peng, Y.-J.; Wei, P.-L.; Lee, C.-H.; Su, H.-Y.; Ho, Y.-S.; Lin, S.-Y.; Wu, C.-H.; Chang, Y.-J. The alpha9 nicotinic acetylcholine receptor is the key mediator in nicotine-enhanced cancer metastasis in breast cancer cells. J. Exp. Clin. Med. 2011, 3, 283-292. [CrossRef]

55. Khan, K.H.; Blanco-Codesido, M.; Molife, L.R. Cancer therapeutics: Targeting the apoptotic pathway. Crit. Rev. Oncol. Hematol. 2014, 90, 200-219. [CrossRef] [PubMed]

56. Wong, R.S. Apoptosis in cancer: From pathogenesis to treatment. J. Exp. Clin. Cancer Res. 2011, $30,87$. [CrossRef] [PubMed]

57. Hanahan, D.; Weinberg, R.A. Hallmarks of cancer: The next generation. Cell 2011, 144, 646-674. [CrossRef] [PubMed]

58. Chonghaile, T.N.; Letai, A. Mimicking the BH3 domain to kill cancer cells. Oncogene 2008, 27, S149-S157. [CrossRef] [PubMed] 
59. Pellecchia, M.; Reed, J.C. Inhibition of anti-apoptotic Bcl-2 family proteins by natural polyphenols: New avenues for cancer chemoprevention and chemotherapy. Curr. Pharm. Des. 2004, 10, 1387-1398. [CrossRef] [PubMed]

60. Garg, R.; Blando, J.; Perez, C.J.; Wang, H.; Benavides, F.J.; Kazanietz, M.G. Activation of nuclear factor B (NF-kB) in prostate cancer is mediated by protein kinase C (PKC ). J. Biol. Chem. 2012, 287, 37570-37582. [CrossRef] [PubMed]

61. Magné, N.; Toillon, R.A.; Bottero, V.; Didelot, C.; Houtte, P. Van; Gérard, J.P.; Peyron, J.F. NF-кB modulation and ionizing radiation: Mechanisms and future directions for cancer treatment. Cancer Lett. 2006, 231, 158-168.

62. Maeng, H.J.; Lee, W.J.; Jin, Q.R.; Chang, J.E.; Shim, W.S. Upregulation of COX-2 in the lung cancer promotes overexpression of multidrug resistance protein 4 (MRP4) via PGE2-dependent pathway. Eur. J. Pharm. Sci. 2014, 62, 189-196. [CrossRef] [PubMed]

63. Aggarwal, B.B.; Gehlot, P. Inflammation and cancer: How friendly is the relationship for cancer patients? Curr. Opin. Pharmacol. 2009, 9, 351-369. [CrossRef] [PubMed]

64. Korbakis, D.; Scorilas, A. Treatment of gastric cancer cells with 5-fluorouracil/leucovorin and irinotecan induces distinct alterations in the mRNA expression of the apoptosis-related genes, including the novel gene BCL2L12. Tumor Biol. 2009, 30, 100-107. [CrossRef] [PubMed]

65. Almeida, L.O.; Abrahao, A.C.; Rosselli-Murai, L.K.; Giudice, F.S.; Zagni, C.; Leopoldino, A.M.; Squarize, C.H.; Castilho, R.M. NFKB mediates cisplatin resistance through histone modifications in head and neck squamous cell carcinoma (HNSCC). FEBS Open Biol. 2014, 4, 96-104. [CrossRef] [PubMed]

66. Li, F.; Sethi, G. Targeting transcription factor NF- $\kappa$ B to overcome chemoresistance and radioresistance in cancer therapy. Biochim. Biophys. Acta Rev. Cancer 2010, 1805, 167-180. [CrossRef] [PubMed]

67. McIlwain, D.R.; Berger, T.; Mak, T.W. Caspase functions in cell death and disease. Cold Spring Harb. Perspect. Biol. 2013, 5, 1-28. [CrossRef] [PubMed]

68. Pillai, G.R.; Srivastava, A.S.; Hassanein, T.I.; Chauhan, D.P.; Carrier, E. Induction of apoptosis in human lung cancer cells by curcumin. Cancer Lett. 2004, 208, 163-170. [CrossRef] [PubMed]

69. Earnshaw, W.C.; Martins, L.M.; Kaufmann, S.H. Mammalian caspases: Structure, activation, substrates, and functions during apoptosis. Annu. Rev. Biochem. 1999, 68, 383-424. [CrossRef] [PubMed]

70. Deveraux, Q.L.; Roy, N.; Stennicke, H.R.; Van Arsdale, T.; Zhou, Q.; Srinivasula, S.M.; Alnemri, E.S.; Salvesen, G.S.; Reed, J.C. IAPs block apoptotic events induced by caspase- 8 and cytochrome c by direct inhibition of distinct caspases. EMBO J. 1998, 17, 2215-2223. [CrossRef] [PubMed]

71. Shioiri, T.; Muroi, M.; Hatao, F.; Nishida, M.; Ogawa, T.; Mimura, Y.; Seto, Y.; Kaminishi, M.; Tanamoto, K.-I. Caspase-3 is activated and rapidly released from human umbilical vein endothelial cells in response to lipopolysaccharide. Biochim. Biophys. Acta 2009, 1792, 1011-1018. [CrossRef] [PubMed]

72. Green, D.R. Apoptotic pathways: Ten minutes to dead. Cell 2005, 121, 671-674. [CrossRef] [PubMed]

73. Devarajan, E.; Sahin, A.A; Chen, J.S.; Krishnamurthy, R.R.; Aggarwal, N.; Brun, A.-M.; Sapino, A.; Zhang, F.; Sharma, D.; Yang, X.-H.; et al. Down-regulation of caspase 3 in breast cancer: A possible mechanism for chemoresistance. Oncogene 2002, 21, 8843-8851. [CrossRef] [PubMed]

74. Staal, J.; Bekaert, T.; Beyaert, R. Regulation of NF-kB signaling by caspases and MALT1 paracaspase. Cell Res. 2011, 21, 40-54. [CrossRef] [PubMed]

75. Inoue, T.; Anai, S.; Onishi, S.; Miyake, M.; Tanaka, N.; Hirayama, A.; Fujimoto, K.; Hirao, Y. Inhibition of COX-2 expression by topical diclofenac enhanced radiation sensitivity via enhancement of TRAIL in human prostate adenocarcinoma xenograft model. BMC Urol. 2013, 13. [CrossRef] [PubMed]

(C) 2016 by the authors; licensee MDPI, Basel, Switzerland. This article is an open access article distributed under the terms and conditions of the Creative Commons by Attribution (CC-BY) license (http://creativecommons.org/licenses/by/4.0/). 